\title{
Accounting Knowledge as a Contributing Intention on Improving Public Accounting Profession
}

\author{
Ria Sandra ALIMBUDIONO ${ }^{1}$
}

Received: June 23, 2020 Revised: July 05, 2020 Accepted: August 10, 2020

\begin{abstract}
Public accountant profile dominated by over-50-year-old people appears to be alarming. The intention towards this profession had better be fostered immediately; therefore, the predictors to boost the intention need to be known. The study examines the influence of accounting knowledge toward the intention to work as public accountant using the Theory of Planned Behavior approach. A survey of 146 students revealed that there was a significantly positive influence of accounting knowledge toward the intention of becoming public accountant, both directly and indirectly, through the mediation of attitudes and perceived behavioral control. Subjective norms did not function as an appropriate mediation. The findings are expected to contribute to universities and professional accounting bodies. The study urges the accounting educators to redesign and reorganize the curriculum, including a more interesting teaching and learning methods. The professional accounting bodies are expected to cooperate with accounting educators in enhancing the internship program and providing real-case study to instill a positive attitude and assurance toward the students' competence, which, in the end, might spark the intention to work as public accountant. That accounting knowledge positively influences the intention toward public accounting profession through the mediation of perceived behavioral control was statistically supported.
\end{abstract}

Keywords: Planned Behavior Theory, Accounting Knowledge, Public Accountant

JEL Classification Code: I21, M40, M41, M51

\section{Introduction}

Recently, less and less people manifest an interest in becoming public accountant, which causes the scarcity of public accountant profession (Suryani et al., 2018). This phenomenon can be seen through the number of accounting firms in Indonesia, which were decreasing from 408 in 2011 to 388 in 2014 (PPPK-Ministry of Finance, 2015). The condition worsened as viewed from the range of ages of Indonesian public accountants. There are $57.55 \%$ of public accountants above the age of 50, and under-30-year-olds only account for $0,94 \%$ (PPPK-Ministry of Finance, 2015).

${ }^{1}$ First Author and Corresponding Author. Lecturer, Faculty of Economic and Business, University of Surabaya, Indonesia [Postal Address: No.56, Tenggilis Mejoyo Road, Kali Rungkut District, Surabaya City, East Java Province, 60294, Indonesia]

Email: humas@unit.ubaya.ac.id ; ria@staff.ubaya.ac.id

(c) Copyright: The Author(s)

This is an Open Access article distributed under the terms of the Creative Commons Attribution Non-Commercial License (https://creativecommons.org/licenses/by-nc/4.0/) which permits unrestricted non-commercial use, distribution, and reproduction in any medium, provided the original work is properly cited.
onrestricted non-commercial
Such situation bothered the professional sustainability of public accountant profession.

The scarcity of public accountants has raised an important question concerning why being a public accountant is less interesting for younger people. Previous studies have revealed various intentions of why people decided to be public accountant; for example, students are reluctant to become public accountant, since they have limited knowledge on what public accountant is (Sawarjuwono, 2013), the scope of work, job satisfaction, and great employee turnover (Suryani et al., 2018; Wen et al., 2018). However, the magnitude of intention in working as accountant depends on intrinsic motivation (Bagley et al., 2012), images (Jackling et al., 2012) and parental influences (Anis \& Hanafi, 2015; Law $\&$ Yuen, 2012). These earlier studies showed that there were great factors influencing the intention of becoming accountants.

In addition, this phenomenon of age gap can be perceived from the intentions of future students who enrolled in accounting department. Accounting departments at any universities accepted large numbers of new students, but only few of them were interested to consider public accountancy 
as their future profession (Yuliansyah, 2016). Only 0.94\% of all public accountants were under the age of 30 (PPPKMinistry of Finance, 2015). This is an important point to warrant a further study. Studies upon selecting accountancy as a profession have been done (Bagley et al., 2012; Byrne et al., 2012; Dalci \& Özyapici, 2018; Omar et al., 2015; Solikhah, 2014), however there is very little study specifically concerning the influence of accounting knowledge toward the intention to work as public accountant.

In relation to the profession of public accountant, an individual is deemed to have a positive attitude toward the profession if he likes it, as it is shown through his perceptions and intrinsic interests. Showing an enjoyable expression while doing activities related to accounting and relatively disregarding the financial rewards reveals that there is a positive attitude toward the profession (Jackling et al., 2012; Solikhah, 2014).

The pressure from stakeholders on the necessity of public accountants in business, as known by the students and parents, can be a motivation (Dalci \& Özyapici, 2018) for them to become public accountants. The pressure itself will create the feeling of "being an important person" if one becomes a public accountant. Furthermore, the students might feel that the society and even the country are in need of reliable public accountants (Sawarjuwono, 2013). Therefore, the students will feel that the public accounting profession is a respectable profession (Byrne et al., 2012; Nelson et al., 2002). This social encouragement, aside from the parents', is one of the principal encouragements in selecting the profession as an accountant (Dalci \& Özyapici, 2018).

Perceived behavioral control deals with an individual's feelings about the ease or difficulty he will experience in performing a behavior. It is an individual control when he assesses the external conditions, which is how far he can acquire and perform the behavior he wants. This control appears because he has self-esteem toward his abilities in executing a task. The level of self-esteem or perceived control depends highly on the availability of resources (fund, time, and skill) and opportunities (Çimen et al., 2011; James \& Hill, 2009). Each person has different requirements of resources. Some may need a lot of resources and are hard to fulfill, but some others need only minimum resources. It all shows that self-esteem is related to what the individual perceives. What someone perceives might change in accordance with certain conditions and situations.

In relation to public accountancy profession, everyone has a belief that he is capable or not to work as a public accountant (Bagley et al., 2012). The capability to work depends on the mastery of the knowledge, ability to maintain professional ethics, such as competence, integrity, confidentiality, objectivity and independence (Lee \& Schmidt, 2014). One can assess oneself and, based on his assessment, perceived behavioral control will appeal and improve in line with the improvement of one's self-esteem.

Intentions are the focus of TPB that exhibit how hard someone is trying to execute a behavior and how great an effort he puts in doing so. If someone has a high intention and has no serious bottlenecks, an actual behavior will occur (Alleyne et al., 2013; Özer, G., 2010). Based on TPB, the intention to have a career as a public accountant is predicted using three components and it will improve along with enhancing accounting knowledge.

Accounting knowledge refers to conceptual knowledge and skills of students to provide accounting information to stakeholders (Locke \& Lowe, 2008; Mohamed \& Lashine, 2003). Profound accounting knowledge might be gained at the undergraduate level (Anis \& Hanafi, 2015). Overall, accounting knowledge can be categorized into five major areas: financial accounting, management accounting, information system accounting, auditing, and taxation. All of these are crucial for a public accountant who provides auditing service, management consulting, tax consulting and system consulting.

In general, the intentions of being public accountant might be noticeable while the students are studying at university (Yuliansyah, 2016). During their study terms, the students gain detailed knowledge about accounting, starting from the ontology and epistemology of accounting to the future prospects of being a public accountant. Such knowledge will be very influential toward the intentions of being a public accountant. A study revealed that knowledge did not have significant impact on intention, since the training design was poor. So, a study investigating knowledge as a principal and significant predictor will need to consider other variable as mediators and that there was a tendency, though sufficiently well-informed, that only the less creative students chose to be accountants. Based on those studies, this research aims to clarify and prove empirically that accounting knowledge has an influence on accounting students' intentions to professionally work as public accountant, based on the Theory of Planned Behavior (TPB). This theory is considered to offer a very common and parsimony approach in explaining various human behaviors (Fishbein \& Ajzen, 2011). In TPB, intentions can be predicted with high accuracy from three principal determinants, i.e., attitudes, subjective norms, and perceived behavioral controls.

TPB is a social psychology theory that can be applicable to study behavioral accounting (Alleyne et al., 2013). The implementation of TPB in behavioral accounting studies, for instance fraud intention in financial reporting and auditor's whistleblowing (Alleyne et al., 2013), intentions in studying accounting (Law \& Yuen, 2012) and intentions towards environmental friendly behavior (Han et al., 2010).

TPB is an extension of the Theory of Reasoned Action. Theory of Reasoned Action asserts that the intentions are 
influenced by two main factors, attitudes and subjective norms. This theory has been utilized to help clarify the intentions to study accounting and the student's attitudes towards accounting. In general, besides attitude and subjective norms, an individual's intentions are also shaped by non-volitional control, which explains that sensing the availability of resources and opportunities to perform a certain behavior. Theory of Planned Behavior complements this factor.

TPB believes that the higher attitudes, subjective norms, and perceived behavioral controls possessed by an individual, the higher the individual's intention. Various studies have asserted that, if an individual has positive attitude, subjective norms and perceived behavioral control, he or she tends to be interested in expressing the behaviors (Bagley et al., 2012).

Attitude is also a tendency of responding to an object consistently, whether one likes it or not. If someone considers something useful to him, he will positively respond to it. On the other hand, if something is not useful, he will respond negatively. Self evaluation is done, then individual will determined whether his intention is excellent for his future or not.

In the last part, it is expected that the results of this study can contributed to accounting education institutions, accounting firms and accounting professional institutions. The accounting education institutions are the place where the students gain accounting knowledge. Therefore, accounting educators should reevaluate and redesign the curriculum, which may help to increase students' intention toward the profession. In addition to educational institutions, this study is also useful to accounting firms and accounting professional institutions, since they get the insight that knowledge makes a great contribution to career intention. Therefore, accounting firms and accounting professional institutions must participate in creating an interesting learning atmosphere, by providing opportunities for internships and creating a real case study. This can avoid a long-drawn professional crisis.

\section{Research Methods}

A questionnaire survey was employed to collect data from seventh semester students of accounting department in a private university in Surabaya. Such population was selected as respondents as those students have studied for three years. They are about to complete their undergraduate degree program and soon determine their future profession. The condition is in line with the objectives of the study, that is, to justify the influence of accounting knowledge toward the intention of working as a public accountant. The number of seventh semester students in accounting department totaled 244. All the students were sent questionnaires and 147 of them were returned completely (60.24\%). The data were collected from March 2018 to May 2018.
Accounting knowledge variables were measured by means of the average value of the students' GPAs and answers to a set of 12 questions listed in the syllabus of Introduction to Accounting, Accounting Information System, Cost Accounting, Taxation and Auditing subject. There are two fundamental questions in each subject.

Students' GPAs portray the mastery of accounting concepts during a 3-year study term. The GPAs were categorized into summa cumlaude $(\mathrm{GPA}>=3,90)$, cumlaude $(3,5<=\mathrm{GPA}<3,9)$, very good $(3,0<=\mathrm{GPA}<3,5)$, good $(2,5<=\mathrm{GPA}<3,0)$, satisfactory $(2,0<=\mathrm{GPA}<2,5)$ and less satisfactory $(\mathrm{GPA}<2,00)$. Then, these are converted to numbers, with the highest score being 100, divided in 15-point range in each category. However, those grades were considered not to be sufficient to represent a comprehensive mastery of the accounting concepts. That was due to the possibility of dishonesty (Winardi et al., 2017) in gaining the grades and absentmindedness. Hence, apart from the GPAs, the students' responses to 12 basic questions were used to obtain the level of the students' knowledge. Total score for 12 basic questions was 100, therefore each questions was worth of 8.3 points. In the end, the conversions of GPAs were combined with the points of the answers to the questions, each of whose proportion amounted to $50 \%$.

Attitude was defined as the feeling of likes or dislikes that leads to a tendency to work as a public accountant. The measurement of attitude variable was carried out using semantic differential method by means of bipolar scale, with $1=$ strongly dislike to $5=$ absolutely like. The measurement of the attitude variable used 10 indicators drawn, with modification, from Accounting Attitude Scale (AAS) created by Nelson and modified by Marriott and Marriott.

Subjective norms refer to social pressures perceived by individuals to have a career in public accounting after attaining undergraduate degree in accounting. The measurement of this variable employed 10 indicators which were the modification of AAS created by Nelson and modified by Marriott and Marriott. The modification was carried out based on the guidance of questionnaire development of Theory of Planned Behavior, that is, TACT (Target, Action, Context, and Time) principles. The measuring process was done using semantic differential method by means of bipolar scale, with the measurement ranging from $1=$ strongly disagree to $5=$ strongly agree .

Perceived behavioral control implies the perceptions by the individuals toward self-assurance and capability to professionally work as a public accountant. The variable was measured using 10 indicators based on the modification of AAS created before and emphasizing assurance and control of behavior perceived by the individuals. The measurement of perceived behavioral control was done using semantic differential method by means of bipolar scale, with the measurement resulted in $1=$ strongly disagree to $5=$ strongly agree. 
Intentions to have a profession as a public accountant refer to the measurement of how great the students' intentions are to work as public accountant. The variable was measured using those 10 indicators emphasizing on how great the students' intentions to work as public accountant. The measurement of the intention variable was conducted through semantic differential method by means of bipolar scale, with the measurement resulted in $1=$ strongly disagree to 5 = strongly agree. The four variables of TPB must be assessed using the measurement containing compatibilities, that is, all variables of TPB should be equivalently defined based on the emphasis of each element.

\section{Results and Discussion}

\subsection{Descriptive Statistics, Validity and Reliability}

Respondents comprised the students who were in their seventh semester in one of the private universities in Surabaya, 41 are males $(38.1 \%)$ and 105 are females $(71.9 \%)$. Based on the GPAs, 4 students $(2.74 \%)$ were summa cumlaude, 34 students $(23.29 \%)$ were cumlaude, 42 students $(28.77 \%)$ were very good, 41 students $(28.06 \%)$ were ranked as good, 21 students $(14.83 \%)$ were satisfactory, and 4 students $(2.74 \%)$ were less satisfactory. The basic accounting knowledge assessed from the questionnaires resulted in a minimum point of 33.33 and a maximum point of 100 , with the mean of 69.81 and standard deviation of 13.67 .

Convergent validity test was executed through the value of loading factor indicators. The test was conducted in two stages as there were items having less score in validity test, resulting in eliminating several indicators, i.e., A1, A2, A8, for attitude variable, SN1, SN2, SN8 for subjective norms variable, $\mathrm{PBC} 1, \mathrm{PBC} 2, \mathrm{PBC} 8$ for perceived behavioral control variable, and IPAP8 for intention on public accountant profession variable. After the second stage of validity test, the remaining indicators' loading value was $>0.50$ and $\mathrm{p}$-value $<5 \%$, so, it can be concluded that all indicators had a proper convergent validity.

Meanwhile, discriminant validity test indicated that all constructs were highly reliable as the construct correlation value toward the construct itself was greater than that of the construct correlation. The results of the discriminant validity tests are presented in Table 1.

The reliability test was completed by analyzing composite reliability and Cronbach's Alpha. The results of the test demonstrated that the value of composite reliability and Cronbach's Alpha reached $>0.70$; therefore, it could be concluded that Attitude, Subjective Norms, Perceived Behavioral Control and Intention on Public Accounting Profession variables had high level of reliability. The results of the reliability tests are presented in Table 2.

Table 1: Construct variable Correlation Value

\begin{tabular}{|l|c|c|c|c|c|}
\hline & AK & ATT & SN & PBC & 0.248 \\
\hline AK & 1.000 & 0.161 & -0.203 & 0.793 & 0.282 \\
\hline ATT & 0.161 & 0.702 & 0.558 & 0.427 & 0.650 \\
\hline SN & -0.203 & 0.558 & 0.738 & 0.789 & 0.305 \\
\hline PBC & 0.248 & 0.793 & 0.427 & 0.705 & 0.745 \\
\hline IPAP & 0.282 & 0.650 & 0.305 & & \\
\hline
\end{tabular}

Table 2: Composite Reliability and Cronbach's Alpha

\begin{tabular}{|l|c|c|}
\hline & Composite reliability coefficients & Cronbach's alpha coefficients \\
\hline AK & 1.000 & 1.000 \\
\hline ATT & 0.871 & 0.826 \\
\hline SN & 0.893 & 0.861 \\
\hline PBC & 0.920 & 0.898 \\
\hline IPAP & 0.916 & 0.895 \\
\hline
\end{tabular}




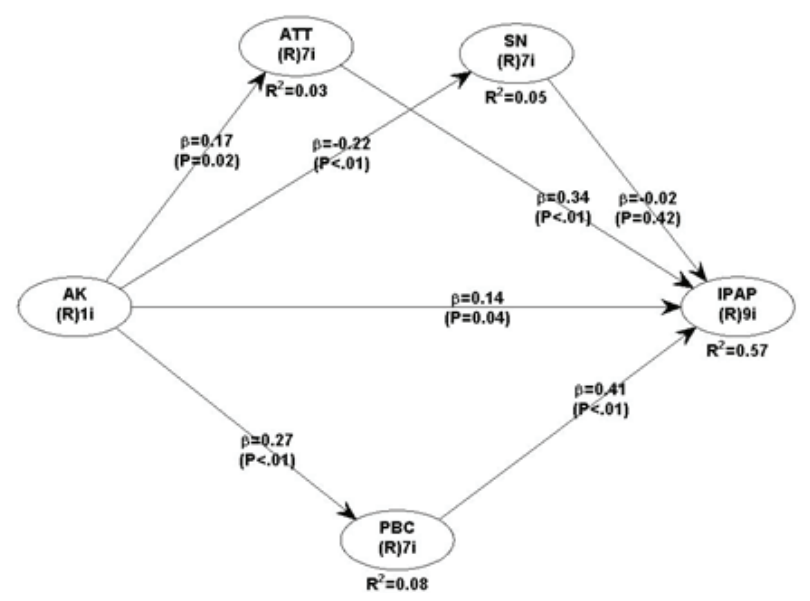

Figure 1: The Result of Structural Model Test

Table 3: Hypothesis Test

\begin{tabular}{|l|c|c|c|c|c|}
\hline \multicolumn{2}{|c|}{} & Path coefficients & P-Value & Statistics results \\
\hline ATT & $\leftarrow$ & AK & 0.173 & 0.015 & Influential \\
\hline SN & $\leftarrow$ & AK & -0.216 & 0.003 & Influential \\
\hline PBC & $\leftarrow$ & AK & 0.274 & $<0.001$ & Influential \\
\hline IPAP & $\leftarrow$ & AK & 0.143 & 0.038 & Influential \\
\hline IPAP & $\leftarrow$ & ATT & 0.340 & $<0.001$ & Influential \\
\hline IPAP & $\leftarrow$ & SN & -0.016 & 0.421 & Not influential \\
\hline IPAP & $\leftarrow$ & PBC & 0.415 & $<0.001$ & Influential \\
\hline
\end{tabular}

Tabel 4: Model Fit

Model fit and quality indices

Average path coefficient $(\mathrm{APC})=0.225, \mathrm{P}=0.001$

Average R-squared $(\mathrm{ARS})=0.180, \mathrm{P}=0.006$

Average block VIF $(\mathrm{AVIF})=1.973$, acceptable if $<=5$, ideally $<=3.3$

Tenenhaus GoF $(\mathrm{GoF})=0.340$, small $>=0.1$, medium $>=0.25$, large $>=0.36$

\subsection{Intention on Public Accounting Profession}

Structural model test using PLS was accomplished by looking at the value of $r$-square as the strength of structural model prediction and the $\mathrm{p}$-value $<5 \%$. The value of $\mathrm{r}$-square refers to goodness of fit model test as seen in the following figure. The results of the hypothesis testing are presented in Table 3.

The results of three fit indicators: average R-square (ARS), average variance inflation factor (AVIF), and average path coefficient (APC) can be seen in Table 3. ARS and APC have $p$-value $<5 \%$, the AVIF value is less than 5 , means that the criteria for the goodness of fit model have been met.
Based on the test, it is obvious that accounting knowledge indeed positively influences the intentions on Public Accounting Profesion (IPAP) with path coefficient $=0.143$ and $p$-value $<5 \%$. This result indicated that $\mathrm{H} 1$ can statistically be supported. The rationale of this study outcomes revealed that the higher the level of one's knowledge, the greater the intentions on Public Accounting Profession. The phenomenon shows that, if students are knowledgeable, then they will have an understanding of the excellent prospects the profession offers. This will trigger the student to learn harder and prepare himself to become a public accountant. This is in line with the expectation of professional accounting bodies that require qualified students to follow rapid and continuous 
change and demands on public accounting profession in terms of the services that accountants are supposed to deliver (Wessels, 2006). Aertsens et al. (2011) states that objective knowledge is very influential on intention, because of the difference between students' ability.

Yet, previous studies stated that students who had relatively lower levels of creativity, were more likely to major in accounting (Holt et al., 2017). They perceived that accountants are introverted, antisocial, boring and are great procedural characteristics people (Holt et al., 2017; Sawarjuwono, 2013). This opinion was strongly denied by Howieson et al. (2014), who states that all the stereotypes images will shift if accounting educators should not only shared accounting knowledge in the form of rules and provided less involvement with conceptual skills or judgment (McDowall \& Jackling, 2010; Setyaningrum et al., 2015).

The second hypothesis, accounting knowledge positively influences the intentions on public accountant profession through the mediation of attitude was also statistically supported with p-value $<5 \%$. Such results were consistent with earlier studies (Bagley et al., 2012; Jackling et al., 2012; Riemenschneider et al., 2011; Wen et al., 2018). With the existence of high accounting knowledge, the students' motivations and abilities are increasing. This plays a very important role in shaping the intention. In line with this study, Law and Yuen (2012) asserted that attitude was the second most important factors affecting the intentions. Despite the presumptions that a public accountant tends to be anti-social, boring, and introverted (Wessels \& Steenkamp, 2009), the intrinsic motivation, high financial rewards, self and professional goals, and eminent prestige of the profession might contribute to the attitude of the students toward the accounting profession.

Contrary to the previous two hypotheses, the third hypothesis - accounting knowledge positively influences the intentions of public accounting profession through the mediations of subjective norms - was not statistically supported. Accounting knowledge was known to negatively influence the subjective norms (path coefficient $=-0.216$, $\mathrm{p}$-value $<5 \%$ ) and the changes of subjective norms were not influential toward the intentions on public accounting profession ( $\mathrm{p}$-value $>5 \%$ ). Based on these results, it can be inferred that the higher accounting knowledge, the more the students are capable of thinking rationally and independently, which leads to lesser roles of important and salient referents. With the lesser roles, those important and closed referents are no longer significant in influencing the students' decisions to determine their career as public accountants. Correspondingly, Byrne et al. (2012) confirmed that such a minute role of salient figures did not affect the choices of a career. Many reference groups may affect student considerations, such as friends, career counsellors, teachers and parents (Jackling et al., 2012). Each referent can provide different advice and, in the end, students must decide according to their attitude and percieved behavioral control themselves. This is a new fact for Asian students and this might happen to millennials who are less dependent on others, especially parents and/or family and more individualistic.

On the other hand, the statement was not in accordance with Law and Yuen (2012) who declared that subjective norms are the most influential factor predicting intentions (Suryono \& Chariri, 2016; Tan \& Laswad, 2009). The differences of the study results are due to the focus of the study, which was the selection of accounting major to study in undergraduate program, not on the selection of the career after graduating from the major. Going along with the advice and studying in accounting, students might possibly feel that accounting is not their passion. Therefore, they have less intention on public accounting profession.

The last hypothesis, that is, accounting knowledge positively influences the intentions on public accounting profession through the mediation of perceived behavioral control, was statistically supported. Perceived behavioral control is the factor that most influences the emergence of intention. This can be seen from the path coefficients of $\mathrm{AK}$ to $\mathrm{PBC}=0.274$ and $\mathrm{PBC}$ to IPAP $=0.415$ with $\mathrm{p}$-value $<0.001$. It is consistent with (Bagley et al., 2012; Solikhah, 2014; Wen et al., 2015). It was due to the fact that the higher the students' accounting knowledge, the more they are able to recognize what competence is needed to work as a public accountant (Tan \& Laswad, 2006). This ability might lead the students to comprehend and be assured of their own capabilities in controlling and doing jobs as a public accountant (Bagley et al., 2012), which would amplify their intentions on public accounting profession. This applies vice versa.

Since the intention to choose a profession is voluntary, self-efficacy to be a qualified accountant becomes the most important aspect. Self-efficacy can arise if there is sufficient accounting knowledge, especially about accountants' scope of work (Sawarjuwono, 2013), relevant professional knowledge needed (Jackling et al., 2012), and ability to work with tight deadlines due to high professional standards (Holt et al., 2017). This study is also in agreement with the findings by Byrne et al. (2012), who suggested that students having higher level of knowledge tended to be successful in their career as a public accountant as they were certain that they could control their work very well and therefore they reached self-fulfillment. Abilities to control behavior, which are obtained through accounting knowledge, both conceptually and technically, and a great career opportunity, might support the students' intentions on public accountant profession (Solikhah, 2014; Wen et al., 2018). 
Yim (2020) defines that firms having individual blockholders use more income-decreasing accruals than those having no individual blockholders. Furthermore, accounting information of firms having individual blockholders is more conservative than that of firms having no individual blockholders. Ha (2020) shows that mission, involvement and inconsistency in organizational culture positively affect the accounting information system of smalland medium-sized firms in Vietnam. Nguyen et al. (2020) states that for the profession, accountants play an important role in not only providing reliable, objective and valuable information to managers at all levels of the enterprise, helping managers and directors to operate the organization and make right decisions, but also implementing regular checking, controlling activities in accordance with terms and conditions in the law, detecting, and promptly correcting economic errors committed in enterprises.

\section{Conclusion}

This study has revealed that the intentions on public accountant profession were influenced by accounting knowledge, either directly or by means of mediation of attitude and perceived behavioral control. Perceived behavioral control functions as the strongest mediator in clarifying how accounting knowledge affects intentions. Intentions on determining a profession are voluntary. Therefore accounting knowledge is needed to increase awareness of the capability to be a qualified public accountant and, in the end, it will promote their intentions. The second notable predictor was attitude. Attitude is also a good mediator because, by mastering accounting knowledge, students become aware of workload, job satisfaction, financial reward, and working atmosphere of a public accountant and this really determines their intentions. Out of expectations, subjective norms were not predictors of the intentions on public accounting profession, nor were those mediations of accounting knowledge and intentions of becoming a public accountant.

Regarding the findings, there are some implications that might be valuable for educational institution, accounting firms and accounting professional bodies. First, the results call for curriculum redesign in any educational institutions. The redesign might include creating attractive teaching techniques and learning strategies, which will facilitate the understanding of the materials more easily. In the end, it is expected that the renewed classroom experience will lead students to improve their capabilities and later to shape their intentions to work as a public accountant. Second, to help improving the intentions, the accounting firms, accounting professional bodies and educational institutions should work together in socializing the real pictures of public accountant profession, particularly regarding the required competence, long-term prospects, prestige of the profession, and job satisfaction of working as such. Third, through the cooperation of these institutions, it is expected that there will be internship programs in accounting firms and real-casebased study methods regarding public accountant profession. All of these changes are meant to deepen the understanding and preference towards the profession, to create the intentions on the profession, and more importantly, the professional sustainability of the public accounting profession will be assured.

Nonetheless, this study might have some limitations. For one thing, it employed knowledge as the only predictor for the intentions. Future studies might involve cultures, ethnicities, and other aspects as determinant factors. Further studies can also be deepened by applying different theories of social psychology that later will enrich the information on factors that affect the interests of being a public accountant. Moreover, the respondents in this study came from one private university. Other respondents from different universities and regions will positively reinforce the generalisation of this study. Yet, apart from its limitations, this study was a though-provoking exercise as it connected accounting knowledge as a trigger of the intentions, using Theory of Planned Behavior approach.

\section{References}

Aertsens, J., Mondelaers, K., Verbeke, W., Buysse, J., \& van Huylenbroeck, G. (2011). The influence of subjective and objective knowledge on attitude, motivations and consumption of organic food. British Food Journal, 113(11), 1353-1378. https://doi.org/10.1108/00070701111179988

Alleyne, P., Hudaib, M., \& Pike, R. (2013). Towards a conceptual model of whistle-blowing intentions among external auditors. British Accounting Review, 45(1), 10-23. https://doi. org/10.1016/j.bar.2012.12.003

Anis, A., \& Hanafi, R. (2015). Factors influencing students' choice of an accounting major in Egypt. International Journal of Accounting, Auditing and Performance Evaluation, 11(3-4), 225-254. https://doi.org/10.1504/IJAAPE.2015.071585

Bagley, P. L., Dalton, D., \& Ortegren, M. (2012). The factors that affect accountants' decisions to seek careers with big 4 versus non-big 4 accounting firms. Accounting Horizons, 26(2), 239-264. https://doi.org/10.2308/acch-50123

Byrne, M., Willis, P., \& Burke, J. (2012). Influences on school leavers' career decisions - Implications for the accounting profession. International Journal of Management Education, 10(2), 101-111. https://doi.org/10.1016/j.ijme.2012.03.005

Çimen, O., Gökmen, A., Altunsoy, S., Ekici, G., \& Yilmaz, M. (2011). Analysis of biology candidate teachers' self-efficacy beliefs on environmental education. Procedia - Social and Behavioral Sciences, 2549-2553. https://doi.org/10.1016/j. sbspro.2011.04.143

Dalci, İ., \& Özyapici, H. (2018). Cultural values and students' intentions of choosing accounting career. Journal of Financial 
Reporting and Accounting, 16(1), 179-196. https://doi. org/10.1108/JFRA-09-2016-0072

Fishbein, M., \& Ajzen, I. (2011). Predicting and changing behavior: The reasoned action approach. In Predicting and Changing Behavior: The Reasoned Action Approach. New York, NY: Psychology Press. https://doi.org/10.4324/9780203838020

Ha, V. D. (2020). Impact of organizational culture on the accounting information system and operational performance of small and medium sized enterprises in Ho Chi Minh City. Journal of Asian Finance, Economics and Business, 7(2), 301-308. https:// doi.org/10.13106/jafeb.2020.vo17.no2.301

Han, H., Hsu, L. T., \& Sheu, C. (2010). Application of the Theory of Planned Behavior to green hotel choice: Testing the effect of environmental friendly activities. Tourism Management, 31(3), 325-334. https://doi.org/10.1016/j.tourman.2009.03.013

Holt, T., Burke-Smalley, L. A., \& Jones, C. (2017). An empirical investigation of student career interests in auditing using the Big Five model of personality. In: Advances in Accounting Education: Teaching and Curriculum Innovations (pp. 1-31). https://doi.org/10.1108/S1085-462220170000020002

Jackling, B., De Lange, P., Phillips, J., \& Sewell, J. (2012). Attitudes towards accounting: Differences between Australian and international students. Accounting Research Journal, 25(2), 113-130. https://doi.org/10.1108/10309611211287305

James, K. L., \& Hill, C. (2009). Race and the development of career interest in accounting. Journal of Accounting Education, 27(4), 210-222. https://doi.org/10.1016/j.jaccedu.2010.07.005

Law, P., \& Yuen, D. (2012). A multilevel study of students' motivations of studying accounting: Implications for employers. Education and Training, 54(1), 50-64. https://doi. org/10.1108/00400911211198896

Lee, W. E., \& Schmidt, D. (2014). A multigroup analysis of students' intention to major in accounting before, during, and after the recession: Emergence of a professional ethics perception. Advances in Accounting Education: Teaching and Curriculum Innovations, 33-57. https://doi.org/10.1108/S1085462220140000015000

Locke, J., \& Lowe, A. (2008). Evidence and implications of multiple paradigms in accounting knowledge production. European Accounting Review, 17(1), 161-191. https://doi. org/10.1080/09638180701819881

McDowall, T., \& Jackling, B. (2010). Attitudes towards the accounting profession: An Australian perspective. Asian Review of Accounting, 18(1), 30-49. https://doi. org/10.1108/13217341011045999

Mohamed, E. K. A., \& Lashine, S. H. (2003). Accounting knowledge and skills and the challenges of a global business environment. Managerial Finance, 29(7), 3-16. https://doi. org/10.1108/03074350310768319

Nelson, I. T., Vendrzyk, V. P., Quirin, J. J., \& Allen, R. D. (2002). No, the Sky Is Not Falling: Evidence of Accounting Student Characteristics at FSA Schools, 1995-2000. Issues in
Accounting Education, 17(3), 269-287. https://doi.org/10.2308/ iace.2002.17.3.269

Nguyen, D. H., Ha, S. T., Tran, M. L., Nguyen, D. T., Nguyen, T. X. H., Nguyen, D. L., \& Do, D. T. (2020). Determinants of Accountants' Loyalty Underlying Investment Management: Evidence from FDI Firms in Thanglong Industrial Park. Journal of Asian Finance, Economics and Business, 7(4), 287-297. https://doi.org/10.13106/jafeb.2020.vol7.no4.287

Omar, M. K., Zakaria, A., Ismail, S., Sin, J. S. L., \& Selvakumar, V. (2015). Job Selection Preferences of Accounting Students in Malaysian Private Universities. Procedia Economics and Finance, 31, 91-100. https://doi.org/10.1016/s22125671(15)01135-1

Özer, G., \& E. Y. (2010). Comparison of the Theory of Reasoned Action and the Theory of Planned Behavior: An Application on Accountants' Information Technology Usage. African Journal of Business Management, 5(1), 50-58

PPPK-Ministry of Finance. (2015). Profile of Public Accountants and Public Accounting Firm 2014. Jakarta, Indonesia: Ministry of Finance of the Republic of Indonesia.

Riemenschneider, C. K., Leonard, L. N. K., \& Manly, T. S. (2011). Students' ethical decision-making in an information technology context: A theory of planned behavior approach. Journal of Information Systems Education, 22(3), 203-214.

Sawarjuwono, T. (2013). Escalating Interest to Be Professional Accountants: Indonesia Case. World, 3(3). [Indonesian]

Setyaningrum, D., Muktiyanto, A., \& Hermawan, A. A. (2015). How Indonesian Accounting Education Providers Meet The Demand of The Industry. International Research Journal of Business Studies, 8(1). https://doi.org/10.21632/ irjbs.8.1.1-11

Solikhah, B. (2014). An Application of Theory of Planned Behavior towards CPA Career in Indonesia. Procedia Social and Behavioral Sciences, 164, 397-402. https://doi. org/10.1016/j.sbspro.2014.11.094

Suryani, A. W., Helliar, C., Carter, A. J., \& Medlin, J. (2018). Shunning careers in public accounting firms: The case of Indonesia. The British Accounting Review, 50(5), 463-480. https://doi.org/10.1016/j.bar.2018.05.001

Suryono, E., \& Chariri, A. (2016). Attitude, Subjective Normal, and Intention of Civil Servants for Combating Violations (WhistleBlowing). Indonesian Journal of Accounting and Finance, 13(1), 102-116. https://doi.org/10.21002/jaki.2016.06

Tan, L. M., \& Laswad, F. (2006). Students' beliefs, attitudes and intentions to major in accounting. Accounting Education, 15(2), 167-187. https://doi.org/10.1080/09639280600787194

Tan, L. M., \& Laswad, F. (2009). Understanding students' choice of academic majors: A longitudinal analysis. Accounting Education, 18(3), 233-253. https://doi.org/10.1080/09639280802009108

Wen, L., Hao, Q., \& Bu, D. (2015). Understanding the Intentions of Accounting Students in China to Pursue Certified Public 
Accountant Designation. Accounting Education, 24(4), 341-359. https://doi.org/10.1080/09639284.2015.1051561

Wen, L., Yang, H. (Chris), Bu, D., Diers, L., \& Wang, H. (2018). Public accounting vs private accounting, career choice of accounting students in China. Journal of Accounting in Emerging Economies, 8(1), 124-140. https://doi.org/10.1108/ JAEE-09-2016-0080

Wessels, P. L. (2006). The South African business environment in which accountants function and the role of information technology in that environment. Meditari Accountancy Research, 14(2), 131-149. https://doi. org/10.1108/10222529200600017

Wessels, P. L., \& Steenkamp, L. P. (2009). An investigation into students' perceptions of accountants. Meditari
Accountancy Research, 17(1), 117-132. https://doi. $\operatorname{org} / 10.1108 / 10222529200900008$

Winardi, R. D., Mustikarini, A., \& Anggraeni, M. A. (2017). Academic Dishonesty among Accounting Students: Some Indonesian Evidence. Jurnal Akuntansi Dan Keuangan Indonesia, 14(2), 142-164. https://doi.org/10.21002/ jaki.2017.08

Yim, S. G. (2020). Individual blockholder's influence on accounting quality: Evidence from Korea. Journal of Asian Finance, Economics and Business, 7(1), 59-69. https://doi.org/10.13106/ jafeb.2020.vol7.no1.59

Yuliansyah, A. W. S. (2016). Challenges in Developing Professional Public Accountants in the Regions. Accountant Magazine, 54-59. [Indonesian] 